\title{
Revitalisasi Bangunan Masjid Al Firdaus Bojong Pondok Terong, Cipayung, Depok
}

\author{
Zainal Arifin Masri' ${ }^{1}$, Bambang Perkasa Alam² \\ Universitas Indraprasta PGRI \\ zarifin243@yahoo.com ${ }^{1}$ perkasaalam.bambang@gmail.com²
}

\begin{abstract}
Abstrak
Kegiatan pengabdian kepada masyarakat (abdimas) ini dilakukan di Kelurahan Bojong Pondok Terong, Kecamatan Cipayung, Kota Depok. Abdimas ini merupakan program kemitraan dengan mitra kerja sama Dewan Kemakmuran Masjid (DKM) Al Firdaus. Masjid Al Firdaus didirikan sekitar tahun 1970-an saat ini merupakan bangunan tua yang dikhawatirkan dapat membahayakan keselamatan jamaah/masyarakat yang sedang melaksanakan ibadah. Di samping itu kapasitas masjid tidak lagi mencukupi untuk menampung jamaah salat Jumat. Oleh karena itu DKM Al Firdaus bermaksud merenovasi bangunan masjid secara total/menyeluruh dengan prinsip dari jamaah, oleh jamaah dan untuk jamaah. DKM Al Firdaus menghadapi kendala di mana tidak ada jamaah masjid yang merupakan tenaga ahli dibidang teknik sipil dan arsitek. Tim dosen abdimas Universitas Indraprasta (Unindra) PGRI menawarkan kepada DKM Al Firdaus kerja sama kemitraan yang saling menguntungkan untuk melaksanakan renovasi masjid Al Firdaus. DKM Al Firdaus menyelesaikan persoalan-persoalan perijinan, kemungkinan adanya gugatan dari ahli waris yang telah mewakafkan tanahnya, adanya keberatan warga/jamaah terhadap renovasi masjid dan lain sebagainya. Sedangkan tim dosen abdimas Unindra PGRI menyiapkan tenaga ahli yang akan mengerjakan tugas-tugas antara lain praperencanaan meliputi meninjau lokasi masjid, luas tanah, bentuk tanah dan struktur tanah, perencanaan berupa desain arsitektur masjid dan rencana anggaran belanja (RAB) dan ikut mengawasi pelaksaan pembangunan dari segi teknis bangunan.
\end{abstract}

Kata Kunci: desain masjid, masjid, renovasi, $R A B$

\section{Revitalization of Al Firdaus Mosque Building Bojong Pondok Terong, Cipayung, Depok}

\begin{abstract}
Tihis community service activities are carried out in the Bojong Pondok Terong Village, Cipayung Subdistrict, Depok City. The Abdimas is a partnership program with Al Firdaus Mosque Prosperity Council (DKM) cooperation partners. Al Firdaus Mosque was founded around the 1970s when it is an old building that is feared could endanger the safety of worshipers / people who are carrying out worship. Besides that, the mosque's capacity is no longer sufficient to accommodate Friday worshipers. Therefore DKM Al Firdaus intends to completely renovate the mosque building with the principles of the congregation, by the congregation and for the congregation. Al Firdaus DKM faced an obstacle in which there were no mosque worshipers who were experts in the field of civil engineering and architects. Unindra's abdimas lecturer team at PGRI offered Al Firdaus DKM a mutually beneficial partnership to carry out the renovation of the Al Firdaus mosque. Al Firdaus DKM resolves licensing issues, the possibility of a lawsuit from the heirs who have donated their land, the objections of residents / worshipers towards the renovation of the mosque and so forth. Meanwhile, the team of Unindra's abdimas PGRI prepared experts who would carry out tasks including pre-planning including reviewing the location of the mosque, land area, land shape and soil structure, planning in the form of mosque architecture design and budget planning $(R A B)$ and participating in supervising the implementation of development from a technical point of view of the building.
\end{abstract}

Keywords: mosque design, mosque, renovation, $R A B$. 
KANGMAS: Karya Ilmiah Pengabdian Masyarakat, 1 (3), November 2020 - 85

http://journal.neolectura.com/index.php/Kangmas

\section{PENDAHULUAN}

Cipayung adalah sebuah kecamatan di Kota Depok, Provinsi Jawa Barat, Indonesia. Kecamatan Cipayung berada di wilayah Kota Depok sebelah selatan. Jumlah kelurahan di Kecamatan Cipayung sebanyak lima kelurahan yaitu Cipayung Jaya, Bojong Pondok Terong, Pondok Jaya, Ratu Jaya, dan Ciapayung. Kecamatan Cipayung merupakan dataran rendah-perbukitan bergelombang lemah dengan ketinggian antara 70-100 meter di atas permukaan laut. Kecamatan Cipayung memiliki luas sekitar 11,63 $\mathrm{km}^{2}$ dengan batas wilayah sebagai berikut :

- Sebelah utara berbatasan dengan Kecamatan Pancoran Mas

- Sebelah selatan berbatasan dengan Kabupaten Bogor

- Sebelah barat berbatasan dengan Kecamatan Sawangan

- Sebelah timur berbatasan dengan Kecamatan Sukmajaya dan Kecamatan Cilodong

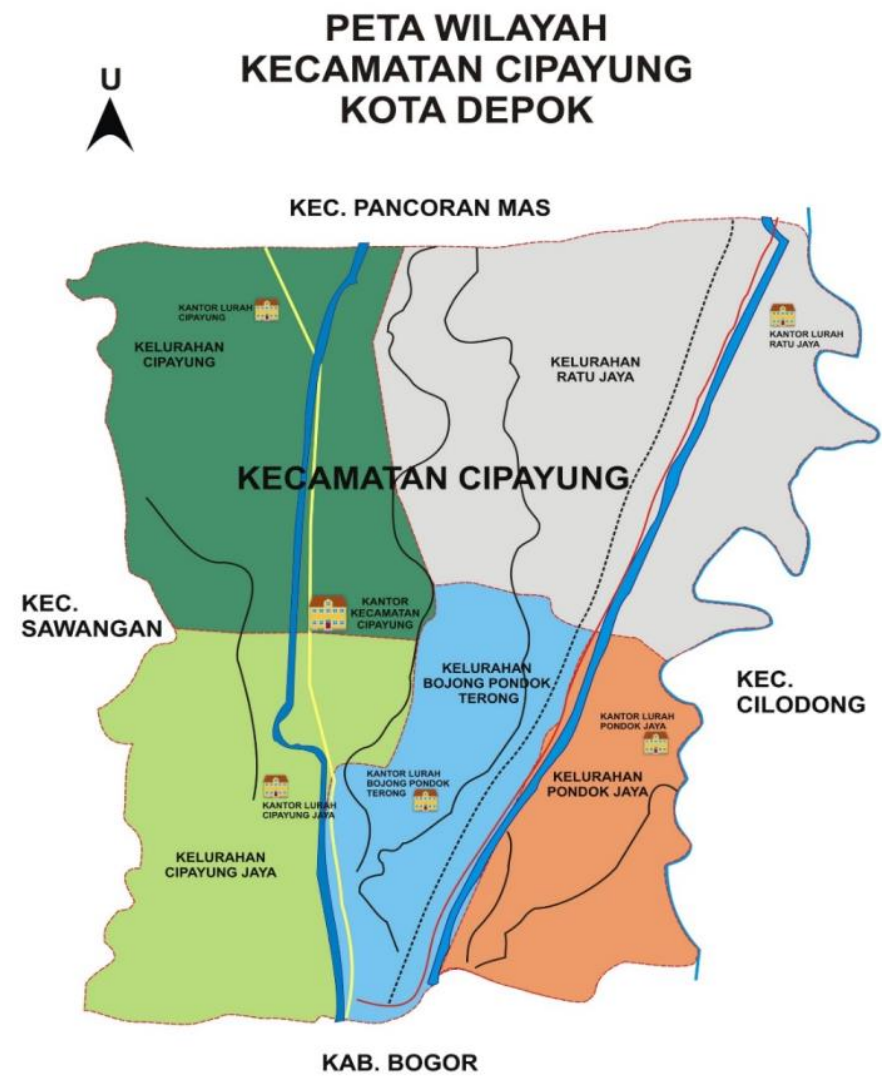

Gambar 1. Peta Kecamatan Cipayung

Sarana prasarana yang dimiliki kecamatan Cipayung antara lain pendidikan mulai dari TK, SD/MI, SLTP/MTs, SMU/SMK/MA dan Pondok Pesantren. Sarana rekreasi antara lain: pemancingan, kolam renang dan danau. Sarana kesehatan adalah rumah sakit, puskesmas, puskesmas pembantu, rumah bersalin, praktik dokter dan bidan. Sarana olah raga adalah GOR Ratu Jaya. Sedangkan sarana transportasi antara lain stasiun kereta api Citayam (BPS Kota Depok, 2019). 
Vol. 1, No. 3,

November

2020

pp. 84-92

e-ISSN:

2722-2004

Title

Revitalization of

Al Firdaus

Mosque

Building Bojong

Pondok Terong,

Cipayung,

Depok

Author

Z. A. Masri,

B. P. Alam

Kecamatan Cipayung terdiri dari 42.200 kepala keluarga, 346 rukun tetangga dan 53 rukun warga. Jumlah penduduk Kecamatan Cipayung sebanyak 148.866 jiwa. Dengan luas wilayah $11,63 \mathrm{~km}^{2}$, setiap $\mathrm{km}^{2}$ ditempati penduduk 12.614 orang. Secara umum jumlah penduduk laki-laki lebih banyak dibandingkan jumlah penduduk perempuan. Jumlah penduduk laki-laki 87.037 jiwa, sedangkan jumlah penduduk perempuan 84.420 Jiwa., total jumlah penduduk kecamatan Cipayung 171.457 jiwa.

Tabel 1. Jumlah Penduduk Menurut Agama di Kecamatan Cipayung

\begin{tabular}{|c|c|c|c|c|c|c|c|c|}
\hline No. & Kelurahan & Islam & Katolik & $\begin{array}{c}\text { Protesta } \\
\text { n }\end{array}$ & Hindu & Buddha & Lainnya & Jumlah \\
\hline 1 & $\begin{array}{l}\text { Cipayung } \\
\text { Jaya }\end{array}$ & 18.846 & 63 & 181 & 41 & 24 & 0 & 19.555 \\
\hline 2 & $\begin{array}{l}\text { Bojong } \\
\text { Pondok } \\
\text { Terong }\end{array}$ & 34.215 & 118 & 620 & 10 & 43 & 37 & 35.043 \\
\hline 3 & Pondok Jaya & 25.351 & 259 & 961 & 34 & 55 & 101 & 26.761 \\
\hline 4 & Ratu Jaya & 36.942 & 503 & 1.568 & 22 & 40 & 2 & 39.677 \\
\hline \multirow[t]{2}{*}{5} & Cipayung & 28.004 & 127 & 586 & 23 & 75 & 15 & 28.830 \\
\hline & Jumlah & $\begin{array}{c}143.35 \\
8\end{array}$ & 1.070 & 3.916 & 130 & 237 & 155 & 149.866 \\
\hline
\end{tabular}

Sumber: BPS Kota Depok (2019)

Tabel 2. Jumlah Sarana Peribadatan di Kecamatan Cipayung

\begin{tabular}{llcccccc}
\hline No & Kelurahan & Masjid & Mushala & Gereja & Pura & Vihara & Jumlah \\
\hline 1 & Cipayung Jaya & 8 & 19 & - & - & - & 27 \\
2 & Bj Pdk Terong & 13 & 29 & 1 & - & - & 43 \\
3 & Pondok Jaya & 8 & 18 & 1 & - & - & 27 \\
4 & Ratu Jaya & 9 & 35 & - & - & - & 44 \\
5 & Cipayung & 10 & 23 & - & - & - & 33 \\
& Jumlah & 48 & 124 & 2 & - & - & 174 \\
\hline
\end{tabular}

Sumber: BPS Kota Depok (2019)

Jumlah masjid terbanyak di Kecamatan Cipayung ada di Kelurahan Bojong Pondok Terong. Di Bojong Pondok Terong juga terdapat tiga pondok pesantren, yaitu PP Arrahmaniah, PP Assalamah dan PP Nurussalaam. Berdasarkan jumlah penduduk, penduduk Bojong Pondok Terong beragama Islam. Hal ini menunjukkan bahwa masyarakat Bojong Pondok Terong adalah masyarakat yang religius islami.

"Ingsun titip tajug lan fakir miskin" demikian Sunan Gunung Jati berpesan pada umat Islam 6 abad yang lalu. Pesan Sunan agar memperhatikan tajug/surau (masjid dalam arti luas) dan fakir miskin kepada umat Islam. Masjid dan atau musala sebagai sarana peribadatan kaum muslimin paling tidak memiliki tiga fungsi. Ketiga fungsi tersebut adalah fungsi ibadah, fungsi tarbiyah dan fungsi ukhuwah islamiyah.

Fungsi ibadah menjadikan masjid sebagai tempat untuk melaksanakan ibadah, masyarakat muslim melakukan salat rawatib (salat lima waktu), salat sunnah, tadarus (mengaji Alquran), salat tarawih pada Bulan Ramadan dan ritualritual ibadah lainnya. Masjid merupakan tempat "bersujud" seorang hamba kepada penciptanya, berkomunikasi, menyucikan hati, menentramkan jiwa, 
sehingga seseorang bisa bersikap santun dan rendah hati, luruh segala kesombongan dan keangkuhan.

Fungsi tarbiyah menjadikan masjid sebagai sarana pembelajaran dan pendidikan umat. Masjid memberikan pembelajaran dan pengajaran mengenai Alquran dan Sunnah yang merupakan pedoman hidup umat Islam. Masjid menjadi tempat penggemblengan masyarakat. Masjid juga melakukan pembinaan kepada generasi muda agar hidup mereka lebih terarah, tidak terjerumus kepada hal-hal yang dapat menimbulkan keresahan masyarakat.

Masjid juga merupakan wadah umat/jamaah untuk saling mengenal satu sama lain. Masjid menciptakan persaudaraan sesama jamaah, jiwa gotong royong, toleransi dan sebagainya. Dari Rahim masjid akan lahir umat berkualitas yang memiliki prinsip-prinsip kebangsaan dan pembangunan, persatuan, persaudaraan, toleransi, efisien, dan produktivitas tinggi yang dibutuhkan dalam pembangunan bangsa dan Negara.

Salah satu masjid yang ada di Bojong Pondok Terong adalah masjid Al Firdaus. Masjid ini dibangun sekitar tahun 1970-an dan menampung jamaah/masyarakat dari Bojong Pondok Terong dan Pondok Jaya yang berada di seberang masjid. Saat ini kondisi masjid (bangunan) sudah tua dan masjid tidak dapat/tidak mampu menampung jamaah salat Jumat, salat id. Oleh karena itu Dewan Kemakmuran Masjid (DKM) Al Firdaus bermaksud mengadakan revitalisasi/renovasi bangunan masjid. DKM melakukan sosialisasi untuk revitalisasi/renovasi masjid kepada jamaah/masyarakat, sesepuh masyarakat, badan wakaf dan stakeholder lainnya.

Berdasarkan analisis situasi dan wawancara dengan pihak DKM tentang kondisi mitra(DKM), ada beberapa kendala yang dihadapi DKM dalam mengelola masjid Al Firdaus, yakni :

1. Dana infak, sedekah, zakat yang diterima oleh masjid lebih kecil dari biaya operasional masjid, sehingga kas masjid menjadi minus. Untuk mengatasi hal tersebut DKM mencari sebanyak mungkin donatur tetap yang bersedia menanggulangi kekurangan biaya operasional semampunya para donatur memberikan.

2. Jamaah tetap masjid berasal dari kalangan masyarakat menengah bawah, yang mana dapat terlihat dari dana masuk lebih kecil dari biaya operasional masjid.

3. Badan wakaf masjid yang terdiri dari para nadzir banyak yang sudah wafat/meninggal, tinggal 1 yang masih hidup Sehingga badan wakaf nyaris tidak berfungsi.

4. Kelebihan masjid salah satunya adalah terletak di jalan raya Citayam RT 01/05 kelurahan Bojong Pondok Terong

\section{METODE PELAKSANAAN}

Kegiatan pengabdian kepada masyarakat ini akan dilakukan pada Maret hingga Juni 2020, dengan tempat pelaksanaan di Masjid Al Firdaus Bojong Pondok Terong, Cipayung, Depok. Kegiatan ini memiliki target atau sasaran menghasilkan gambar desain arsitektur Masjid Al Firdaus yang baru. Subjek kegiatan adalah Masjid Al Firdaus, pengurus DKM dan jamaah masjid. 
Vol. 1, No. 3,

November

2020

pp. $84-92$

e-ISSN:

2722-2004

Title

Revitalization of

Al Firdaus

Mosque

Building Bojong

Pondok Terong,

Cipayung,

Depok

Author

Z. A. Masri,

B. P. Alam

Jamaah masjid Al Firdaus menghimbau kepada pengurus DKM untuk melakukan renovasi masjid karena kondisi masjid yang sudah tidak mampu menampung jamaah ibadah salat Jumat dan salat id baik Idulfitri mau pun Iduladha. DKM menampung aspirasi jamaah dengan menghubungi tim abdimas Unindra PGRI untuk bekerja sama membantu membuat desain arsitektur masjid.

Ada pun instrumen yang akan digunakan tim abdimas Unindra PGRI adalah peralatan untuk membuat gambar seperti laptop dengan software yang dibutuhkan dan kertas kalkir. Semua instrumen disediakan oleh tim abdimas Unindra PGRI. Setelah melakukan analisis situasi baik ekonomi, sosial dan budaya terhadap masyarakat di mana kegiatan pengabdian kepada masyarakat ini akan dilaksanakan.

Tim dosen abdimas Unindra PGRI bersilaturahmi menemui jajaran pengurus DKM Al Firdaus bertukar pikiran dan berdiskusi mengenai revitalisasi bangunan masjid. Penawaran kerja sama yang diajukan tim dosen abdimas diterima dengan baik karena bersesuaian dengan permintaan dan rencana kerja DKM yang akan melakukan renovasi total bangunan masjid. Metode pelaksanaan yang digunakan dalam kegiatan abdimas ini adalah bantuan perencanaan desain masjid dengan rencana anggaran belanja pembangunan masjid, pengawasan pelaksanaan pembangunan dan hal lainnya yang diminta oleh DKM kepada tim dan tim mampu melaksanakannya. Kegiatan abdimas ini dilaksanakan di Masjid Al Firdaus yang terletak di Jalan Raya Citayam RT 01/05 Bojong Pondok Terong. Kegiatan ini dilakukan dengan melalui beberapa tahapan sebagai berikut :

1. Sosialisasi rencana renovasi total masjid Al Firdaus kepada badan wakaf, jamaah, masyarakat, sesepuh masyarakat dan stakeholder lainnya.

2. Pra persiapan tim abdimas: meninjau lokasi, luas tanah, surat tanah, bentuk dan struktur tanah, daya tampung yang diinginkan

3. Perencanaan: menggambar desain masjid dengan RAB

4. Pembentukan panitia pembangunan masjid Al Firdaus

5. Pelaksanaan pembangunan

DKM Al Firdaus sebagai mitra kerja sama dalam kegiatan pengabdian kepada masyarakat yang akan dilakukan bersama tim dosen abdimas Unindra PGRI disepakati hal-hal yang harus dilakukan oleh DKM adalah:

1. Sosialisasi rencana renovasi total masjid Al Firdaus

2. Menunjukkan bangunan masjid yang akan direnovasi dan surat-surat kepemilikan masjid (akta wakaf)

3. Pembentukan panitia pembangunan masjid Al Firdaus

\section{HASIL DAN PEMBAHASAN}

Masjid Al Firdaus merupakan salah satu masjid yang berada di kelurahan Bojong Pondok Terong Kecamatan Cipayung Kota Depok. Masjid ini dibangun sekitar tahun 1970-an dan menampung jamaah/masyarakat dari Bojong Pondok Terong dan Pondok Jaya yang berada di seberang masjid. Karena letaknya di pinggir jalan raya Citayam masjid juga menampung jamaah musafir yang singgah 
untuk melakukan ibadah salat. Saat ini kondisi bangunan masjid sudah tua dan masjid tidak dapat/tidak mampu menampung jamaah salat Jumat, salat id. Oleh karena itu Dewan Kemakmuran Masjid (DKM) Al Firdaus bermaksud mengadakan revitalisasi/renovasi bangunan masjid.

Ketua DKM Al Firdaus bapak Endang Rosadi mengutarakan maksud dan niatnya untuk melakukan revitalisasi bangunan masjid kepada jamaah tetap masjid Al Firdaus. Salah satu jamaah yakni bapak Zainal Arifin yang merupakan seorang dosen di Universitas Indraprasta PGRI menyambut baik maksud dan niat DKM untuk melakukan revitalisasi bangunan masjid. Namun demikian banyak kendala yang dihadapi DKM dalam mengelola masjid dan dalam rangka melakukan revitalisasi masjid antara lain:

1. Dana infak, sedekah, zakat yang diterima oleh masjid lebih kecil dari pada biaya operasional masjid, sehingga kas masjid menjadi minus. Untuk mengatasi hal tersebut DKM mencari sebanyak mungkin donator tetap yang bersedia menanggulangi kekurangan biaya operasional semampunya para donator memberikan.

2. Jamaah tetap masjid berasal dari kalangan masyarakat menengah bawah, yang mana dapat terlihat dari dana masuk lebih kecil dari biaya operasional masjid.

3. Badan wakaf masjid yang terdiri dari para nadzir banyak yang sudah wafat/meninggal, tinggal 1 yang masih hidup Sehingga badan wakaf nyaris tidak berfungsi.

Ketua DKM meminta kepada jamaah masjid untuk mencarikan tenaga ahli/arsitek untuk membantu membuat desain bangunan masjid. Permintaan disanggupi oleh salah satu jamaah sebagaimana disebutkan di atas dan berjanji dalam waktu dekat akan mempertemukan tenaga ahli/arsitek dengan DKM Al Firdaus.

Pada 4 Februari 2020 di RM Betawi "Mpok Eli" tim dosen Universitas Indraprasta PGRI yang terdiri dari Bambang Perkasa Alam, ST, MM, Ir. Zainal Arifin H. Masri, MM dan seorang mahasiswa arsitektur bertemu dengan ketua DKM Al Firdaus untuk membicarakan rencana kegiatan revitalisasi bangunan masjid Al Firdaus. Berdasarkan pertemuan tersebut disepakati beberapa hal:

1. Tim dosen Unindra PGRI sepenuhnya akan membantu pelaksanaan revitalisasi pembangunan masjid Al Firdaus mulai dari rancangan desain bangunan masjid dengan rencana anggaran belanja (RAB) sampai dengan pengawasan pelaksanaan pembangunan.

2. Keterlibatan tim dosen bisa dijadikan kegiatan pengabdian kepada masyarakat dan ketua DKM akan menyediakan dokumen yang dibutuhkan oleh tim dosen.

3. Tahapan-tahapan rencana kegiatan revitalisasi masjid Al Firdaus yang melibatkan tim dosen sebagai berikut:

a. Pra perencanaan antara lain peninjauan lokasi, melihat bentuk tanah dan ukuran tanah, pemeriksaan gambar awal dan pengukuran, diskusi dengan pengurus DKM Al Firdaus mengenai rancangan yang diinginkan, kapasitas/daya tamping masjid yang diinginkan

b. Perencanaan meliputi rancangan awal beserta alternatifnya, pemilihan rancangan. 
Vol. 1, No. 3,

November

2020

pp. 84-92

e-ISSN:

2722-2004

c. Pengawasan pelaksanaan pembangunan masjid sesuai dengan pilihan desain yang terpilih.

Pada 10 Maret 2020 tim dosen beserta seorang mahasiswa arsitektur berkunjung ke lokasi masjid Al Firdaus untuk meninjau lokasi, melihat bentuk tanah, mengukur luas tanah, melihat kondisi masjid dan berdiskusi dengan pengurus DKM Al Firdaus. Hasil dari kunjungan ini diperoleh antara lain :

1. Lokasi masjid terletak di Jalan Raya Citayam No. 73 Bojong Pondok Terong Cipayung Depok.

2. Bentuk dan luas tanah sebagai berikut:

\section{Title}

Revitalization of

Al Firdaus

Mosque

Building Bojong

Pondok Terong,

Cipayung,

Depok

$18 \mathrm{~m}$

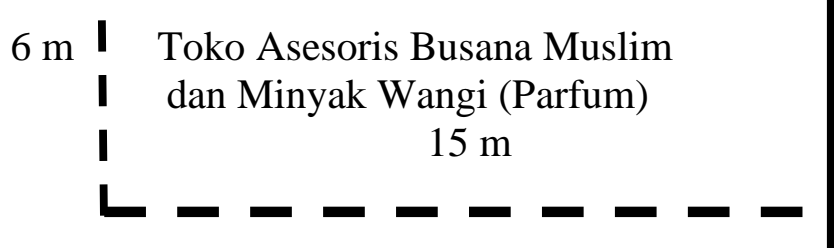

Areal Masjid $\left( \pm 324 \mathrm{~m}^{2}\right)$

\section{Author}

3. Kesepakatan tim dosen dengan pengurus DKM Al Firdaus, bahwa rancangan desain bangunan senantiasa dikonsultasikan dengan DKM, sampai terpilih rancangan final desain bangunan.

Sampai dengan berakhirnya kegiatan pengabdian masyarakat, tim dosen akhirnya berhasil membuat rancangan desain bangunan Masjid Al Firdaus yang sesuai dengan permintaan atau keinginan pengurus DKM. Ada pun foto-foto kegiatan dan hasil rancangan desain arsitektur masjid dapat dilihat di bawah ini:

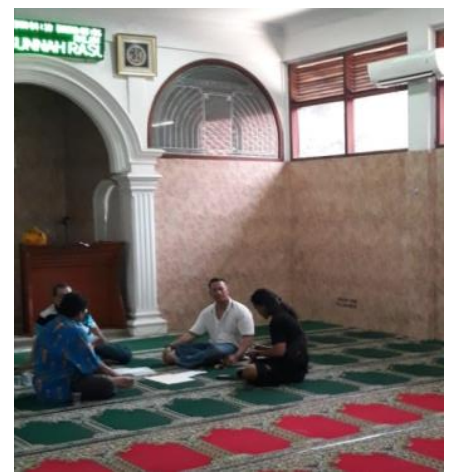

Gambar 2. Tim abdimas tengah berbincang dengan pengurus DKM 
KANGMAS: Karya Ilmiah Pengabdian Masyarakat, 1 (3), November 2020 - 91 http://journal.neolectura.com/index.php/Kangmas
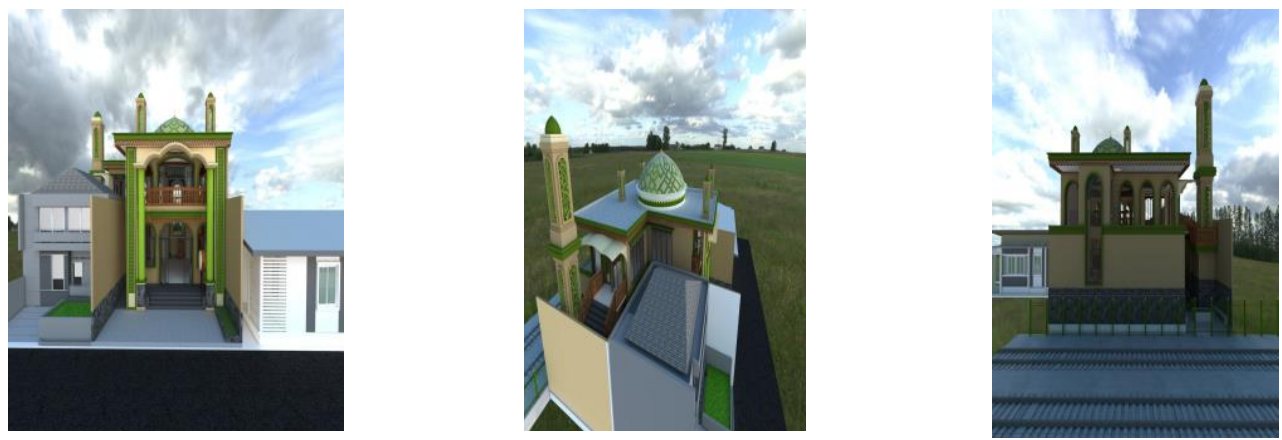

Gambar 3. Ilustrasi Masjid Al Firdaus Bojong Pondok Terong setelah direvitalisasi

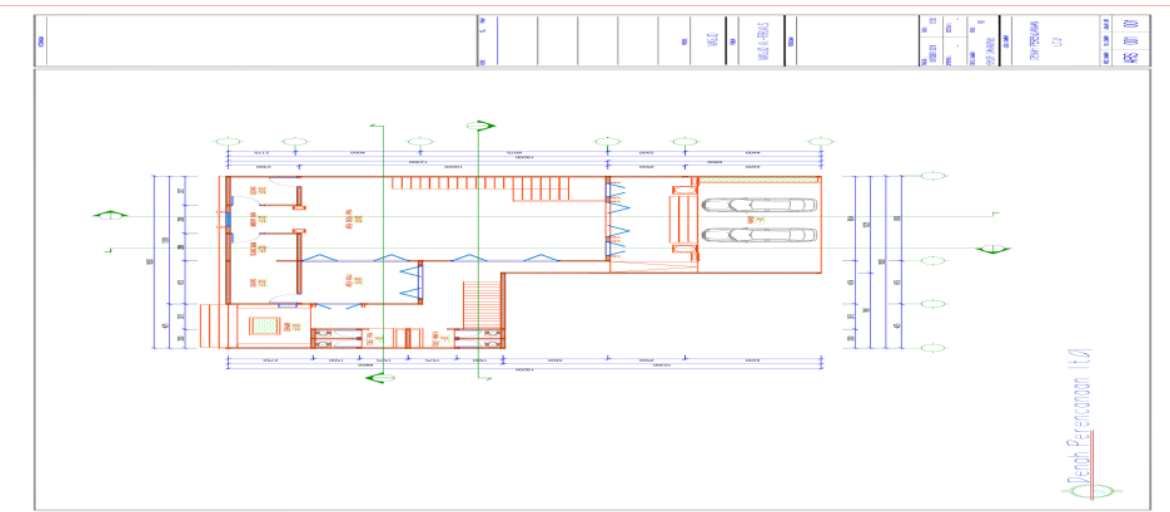

Gambar 4. Rancangan desain lantai dasar Masjid Al Firdaus Bojong Pondok Terong

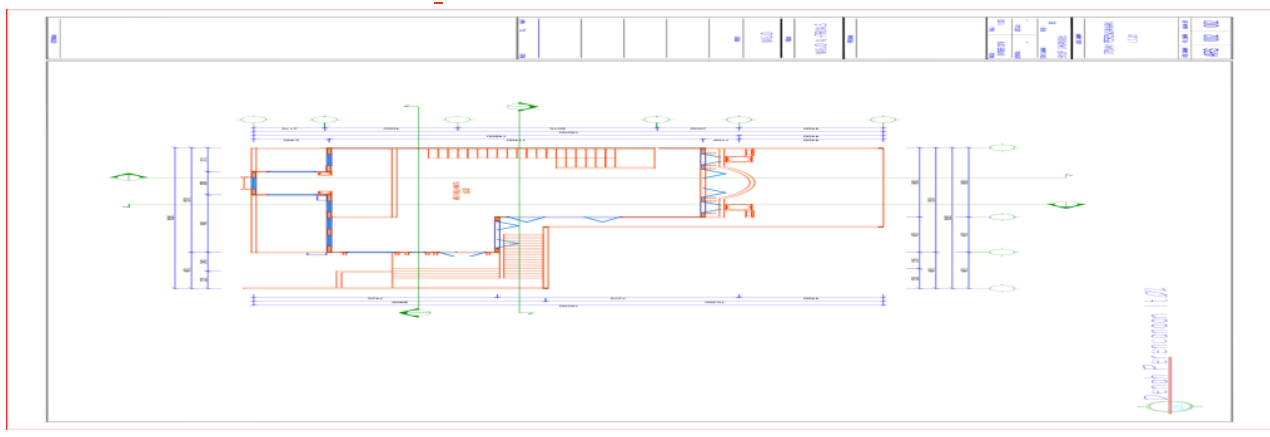

Gambar 5. Rancangan desain lantai atas Masjid Al Firdaus Bojong Pondok Terong

\section{SIMPULAN}

Berdasarkan kegiatan pengabdian kepada masyarakat yang telah dilakukan maka telah berhasil dibuat gambar desain arsitektur masjid Al Firdaus yang sesuai dengan keinginan DKM. Masalah pelaksanaan pembangunan diserahkan kepada DKM dan masyarakat, dengan catatan apabila DKM dan masyarakat membutuhkan keterlibatan tim abdimas Unindra PGRI maka tim abdimas bersedia melakukan kegiatan abdimas untuk periode berikutnya. 
KANGMAS: Karya Ilmiah Pengabdian Masyarakat, 1 (3), November 2020 - 92

http://journal.neolectura.com/index.php/Kangmas

\section{DAFTAR PUSTAKA}

Vol. 1, No. 3,

November

2020

pp. $84-92$

e-ISSN:

2722-2004

\section{Title}

Revitalization of

Al Firdaus

Mosque

Building Bojong

Pondok Terong,

Cipayung,

Depok

Author

Z. A. Masri,

B. P. Alam
Ayub, M. dkk. (2001). Manajemen Masjid: Petunjuk Praktis Bagi Pengurus. Jakarta: Gema Insani Press

Baijuri, A. (2017). Memandang Fungsi dan Peran Masjid. Serang, Banten. Banten: Kantor Wilayah Kementerian Agama Provinsi Banten.

BPS Kota Depok. (2019). BPS Kota Depok, Kecamatan Cipayung Dalam Angka 2019, Cipayung District in Figure.

Budiman, M. (n.d.). Manajemen Masjid. Jakarta: Ziyad

https://aldayub.wordpress.com/materi-kuliah/peran-dan-fungsi-masjid/ diunggah . Senin, 17 Februari 2020 15:28 WIB

Suprianto, A. (2017). Peran dan Fungsi Masjid. Jakarta: Cahaya Hikmah 